\title{
PREVALENCE OF CRYPTOCOCCAL MENINGITIS IN A TERTIARY CARE CENTRE
}

\author{
Ashish Bajaj1, Bibhabati Mishra2, Poonam S Loomba2, Archana Thakur3, Abha Sharma4, \\ Prachala G Rathod1, Madhusmita Das1, Ashna Bhasin1 \\ 1Senior Resident, 2Director Professor, 3Director Professor \& Head, 4Assistant Professor, \\ Department of Microbiology, Govind Ballabh Pant Institute of Postgraduate Medical Education \\ and Research (GIPMER), New Delhi, India
}

\section{ABSTRACT}

Background: Cryptococcal meningitis has emerged as an important opportunistic central nervous system (CNS) infection in Human Immunodeficiency Virus (HIV) positive patients. It is associated with a high mortality rate. Hence early diagnosis is necessary to start appropriate treatment. Cryptococcosis is generally found in association with acquired immunodeficiency syndrome (AIDS) although it has been reported to cause disease in HIV-seronegative patients also.

Objective: Prevalence of Cryptococcal meningitis in a tertiary care centre.

Material \& Methods: A total of 93 Cerebrospinal fluid samples from suspected cases of fungal meningitis were received in the microbiology department of GB Pant Hospital(GIPMER) from January to June 2018. Samples were subjected to direct microscopy- wet mount, India ink preparation and Gram stain, Cryptococcal antigen detection(Latex agglutination), and Fungal culture. In vitro susceptibility of Cryptococcus isolates to Fluconazole, Voriconazole, 5Flucytosine and Amphotericin B was performed using standard broth microdilution method.

Results: Out of 93 CSF samples, 6 were positive for India ink preparation and showed gram positive budding yeast cells by gram staining. All 6 samples were positive for the cryptococcal antigen test and fungal culture. Five were identified as $C$. neoformans and one $C$. gatti. All strains were susceptible to Amphotericin B. Four patients were HIV reactive and succumbed to the diseaseduring treatment. Two patients were found to be coinfected with Hepatitis B virus.

Conclusion: Index of suspicion of Cryptococcus infection as a possible cause of meningitis must be considered in chronic meningitis cases. Microscopy (India ink preparation) may be used as a cheap and rapid diagnostic tool.

Keywords: Chronic meningitis, HIV, Cryptococcus, India ink

\section{INTRODUCTION}

Cryptococcal meningitis has emerged as an important opportunistic central nervous system (CNS) infection in immunosuppressed patients. It is associated with a high mortality rate $(>30 \%)$ in immunosuppressed patients especially those infected with $\mathrm{HIV}$, hence early diagnosis is necessary to start appropriate treatment. Prevalence of cryptococcal infection is increasing in developing nations including India as per some recent studies.(1) 
Cryptococcosis is most commonlyassociated with patients suffering from acquired immunodeficiency syndrome (AIDS) but also being reported in HIV seronegative patients.(2) Cryptococcal infection occurs through inhalation of fungal spores and their spread via hematogenous route with an increased predisposition for the central nervous system leading to lethal disease. Clinical manifestations include fever, disorientation, headache, various neural dysfunctions etc. Suspected cases of fungal meningitis in immunocompromised as well as immunocompetent patients warrants for cerebrospinal fluid examination to rule out Cryptococcus as a probable etiology. Here we studied the prevalence of cryptococcal meningitis alongwith their laboratory findings and antifungal susceptibility in a tertiary care centre.

\section{MATERIAL\& METHODS}

A cross-sectional study was conducted in Microbiology department of Govind Ballabh Pant Institute of Postgraduate Medical Education and Research (GIPMER), New Delhi from January to June 2018. A total of 93 Cerebrospinal fluid samples from suspected cases of fungal meningitis were included in the study. Processing of all samples were done for Direct microscopy including wet mount, India ink preparation and Gram stain. Serological test was performed for Cryptococcal antigen detection(Latex agglutination (Pastorex Crypto Plus by BIO-RAD) on all CSF samples. Fungal culture was performed on two sets of SDA (Sabouraud's Dextrose Agar) and incubated at $25^{\circ} \mathrm{C}$ and $37^{\circ} \mathrm{C}$, for 4 weeks. Identification was done as per colony morphology, spherical yeast cells on staining and positive urease test in case of Cryptococcus neoformans. Speciation of yeast isolate was performed with Automated (Vitek 2-compact by Biomerieux) systems and Antifungal Susceptibility testing by Standard broth microdilution method.

\section{RESULTS}

Out of 93 CSF samples received from suspected fungal meningitis cases, 6 were positive for India ink preparation and showed gram positive budding yeast cells by gram staining. The prevalence of cryptococcal meningitis in present study was 6.45\% (6/93). All 6 samples were positive for cryptococcal antigen test and Fungal culture on SDA. Risk factors and light microscopic findings are depicted in Table 1. Four patients were HIV reactive and succumbed to disease during the treatment. Two patients were found to be coinfected with Hepatitis B.Five strains were identified as $C$. neoformans and one as $C$. gatti. All strains were susceptible to Amphotericin B. One strain was resistant to fluconazole. Antifungal susceptibility of all cryptococcal isolates with their minimum inhibitory concentration (MICs) is compiled in Table 2. Gram stain (1a,1b) and India ink $(2 a, 2 b)$ findings are shown in Figure 1 \& 2, respectively. Table 3 depicts the occurrence of presenting symptoms of patients with cryptococcal meningitis.

\section{DISCUSSION}

Cryptococcal meningitis is one of the most common fatal opportunistic infection found in patients suffering from HIV and AIDS. In these patients the disease is almost incurable due to persisting comorbidities. Clinical presentation and the course of meningitis are usually indolent with symptoms starting over 1-3 weeks. Usual symptoms are headache and altered mental status, including personality changes, and confusion. In this study, headache and fever were most common presenting symptoms followed by vomiting and altered sensorium. Similar findings were reported by study done in 2017.(3-4) 
Recent reports have described catastrophic loss of vision in patients without evidence of endophthalmitis. The funduscopic examination was either normal or revealed evidence of papilledema.(5)We got similar finding of papilledema in 2(33.33\%) cases.Study in 2017 reported 7 cases with papilledema.(3)

HIV infection is the strongest of all known risk factors for the development of tuberculosis. Adequate cell mediated immunity is the crucial host defence against M. tuberculosis. As HIV infection primarily affects the components of cellmediated immunity, thus latent tuberculosis infection gets reactivated in this stratum of patients. Moreover, the infection is poorly contained following reactivation, resulting in widespread dissemination causing extrapulmonary disease.(6)Among HIV positive patients in present study, we found $3 / 4(75 \%)$ cases suffering from tuberculosis as similar finding. A study in 2017 reported that out of 97 cases investigated, 19 cases were coinfected with tuberculosis.(3)

In present study, 4 HIV positive patients died due to complications arising as a result of Cryptococcosis. Recent study also quoted Cryptococcal meningitis as a common and fatal opportunistic neuroinfection seen in immunosuppressed as well as few immunocompetent individuals. Clinical manifestations include acute or subacute fever, headache, vomiting, and focal neurological deficits.(7)

We found one non-HIV patient with C.gattii infection which supports the evidence that strains of $C$. neoformans var. gattii generally infect apparently normal hosts and rarely infect AIDS patients.(5) Both non-HIV patients took full course of treatment but was lost on follow up after discharge from hospital.

India ink and Cryptococcal antigen test in CSF was positive in all patients. Similar finding was observed in study done in a tertiary care hospital in North India.(8) This proves the importance of simple microscopic techniques which can be used as a tool of initial investigation at primary health centres and thus help in early diagnosis and treatment.

The prevalence of Cryptococcal meningitis (6.45\%) in the present study is quite lower as compared to various other Indian studies (Table 4) done in previous years, which may be primarily due to less duration of study and lower sample size.Recent studies from Indian subcontinent compiled in Table 4 denotes the higher prevalence and mortality in patients diagnosed with cryptococcal meningitis.

Increased number of cases of chronic meningitis diagnosed as cryptococcal meningitis in both immunocompromised and immunocompetent patients is alarming and steps should be ensured to early diagnosis and treatment of the same.

\section{CONCLUSION}

Index of suspicion of Cryptococcus infection as a possible cause of meningitis must be considered in chronic meningitis cases. Microscopy (India ink preparation) may be used as cheap rapid diagnostic tool.Early diagnosis and prompt treatment of meningitis are of paramount importance in reducing the morbidity and mortality in both HIV infected and non HIV infected population.

\section{ACKNOWLEDGEMENT}

We would to like acknowledge Dr. Immaculata Xess, Department of Microbiology, All India Institute of Medical Sciences(AIIMS), New Delhi for help in identification and antifungal susceptibility testing.

\section{CONFLICT OF INTEREST: Nil}


www.pimr.org.in

\section{REFERENCES}

1. Gupta P, Malik S, Khare V, Banerjee G, Mehrotra A, Mehrotra S, et al. A fatal case of meningitis caused by Cryptococcus neoformans var. grubii in an immunocompetent male. J Infect Dev Ctries 2011;5:71-4.

2. Das S, Datt S, Roy P, Saha R, Xess I. Sporadic occurrence of cryptococcal meningitis in HIV-seronegative patients: Uncommon etiology? Indian J Pathol Microbiol 2017;60:2368.

3. Naik KR, Saroja AO, Doshi DK. Hospital-based retrospective study of cryptococcal meningitis in a large cohort from India. Ann Indian Acad Neurol 2017;20:225-8.

4. Abhilash K, Mitra S, Arul J, Raj PM, Balaji V, Kannangai R, et al. Changing paradigm of Cryptococcal meningitis: An eight-year experience from a tertiary hospital in South India. Indian J Med Microbiol 2015;33:25-9.

5. Mitchell TG, Perfect JR. Cryptococcosis in the era of AIDS--100 years after the discovery of Cryptococcus neoformans. Clin Microbiol Rev. 1995 Oct;8(4):515-48. PMID: 8665468; PMCID: PMC172874.

6. Sharma R, Duggal N, Malhotra S, Shrivastava D, Hans C. Prevalence of cryptococcal meningitis amongst HIV seropositive cases from a tertiary care hospital. International Journal of Current Research and Review. Vol 06 Issue 14, July, 32-37.

7. Pyrgos V, SeitzAE, Steiner CA, Prevots DR, Williamson PR. Epidemiology of cryptococcal meningitis in the US: 1997-2009. PLoS One 2013;8:e56269.

8. Kumar S, Wanchu A, Chakrabarti A, et al. Cryptococcal meningitis in HIV infected: experience from a North Indian tertiary center. Neurol India. 2008;56:444-449.

9. Lungran P, Devi AV, Singh WS, Damroulien S, Mate H,Golmei A. Cryptococcosis: Its prevalence and clinical presentation among HIV positive and negative patients in Rims, Manipur. IOSR J Dent Med Sci 2014;7:38-41.

10. Duggal S, Duggal N, Hans C, Duggal AK (2014) Epidemiology of Cryptococcal Meningitis Associated with HIV in an Indian Hospital . Epidemiol 4: 166. doi:10.4172/21611165.1000166

11. Dash M, Padhi S, Sahu R, Turuk J, Pattanaik S, Misra P. Prevalence of cryptococcal meningitis among people living with human immunodeficiency virus/acquired immunodeficiency syndrome in a Tertiary Care Hospital, Southern Odisha, India. J Nat Sc Biol Med 2014;5:324-8.

12. Danave D, Kulkarni V. A study on cryptococcal meningitis. Journal of Evolution of Research in Medical Microbiology 2016; Vol. 2, Issue 1, Jan-June 2016; Page: 1-2.

13. Kadam D, Chandanwale A, Bharadwaj R, Nevrekar N, Joshi S, Patil S, et al. High prevalence of cryptococcal antigenaemia amongst asymptomatic advanced HIV patients in Pune, India. Indian J Med Microbiol 2017;35:105-8. 
Table 1: Risk factors and light microscopic findings

\begin{tabular}{|c|c|c|c|c|c|}
\hline $\begin{array}{c}\text { Patient } \\
\text { No. }\end{array}$ & Age/sex & Diagnosis & Risk factor & $\begin{array}{c}\text { India ink/Wet } \\
\text { mount }\end{array}$ & Cryptococcal Antigen test \\
\hline 1 & $33 / \mathrm{M}$ & $\begin{array}{c}\text { Pulmonary Koch's } \\
\text { with Intracranial } \\
\text { tuberculoma }\end{array}$ & HIV+ & Positive & Positive \\
\hline 2 & $33 / \mathrm{F}$ & $\begin{array}{c}\text { Old treated case of } \\
\text { TB meningitis }\end{array}$ & HIV+ & Positive & Positive \\
\hline 3 & $28 / \mathrm{M}$ & $\begin{array}{c}\text { Tubercular } \\
\text { Meningitis with } \\
\text { Hydrocephalus }\end{array}$ & HIV + & Positive & Positive \\
\hline 4 & $45 / \mathrm{M}$ & $\begin{array}{c}\text { Chronic Meningitis } \\
\text { with Viral Hepatitis }\end{array}$ & $\begin{array}{c}\text { HIV-HBsAg } \\
+\end{array}$ & Positive & Positive \\
\hline 5 & $19 / \mathrm{M}$ & $\begin{array}{c}\text { Chronic Meningitis } \\
\text { with Viral Hepatitis }\end{array}$ & $\begin{array}{c}\text { HIV- } \\
\text { HBsAg }+\end{array}$ & Positive & Positive \\
\hline 6 & $60 / \mathrm{F}$ & Chronic Meningitis & HIV + & Positive & Positive \\
\hline
\end{tabular}

Table 2: Antifungal susceptibility of Cryptococcal isolates

\begin{tabular}{|c|c|c|c|c|c|}
\hline \multirow{2}{*}{$\begin{array}{l}\text { Patient } \\
\text { No. }\end{array}$} & \multirow[t]{2}{*}{ Fungal Species } & \multicolumn{4}{|c|}{ MICs $(\mu \mathrm{g} / \mathrm{ml})$} \\
\hline & & $\begin{array}{c}\text { Amphotericin B } \\
\text { (Amp-B) }\end{array}$ & $\begin{array}{l}\text { 5-Flucytosine } \\
\text { (5-FTC) }\end{array}$ & $\begin{array}{l}\text { Fluconazole } \\
\text { (FZ) }\end{array}$ & $\begin{array}{c}\text { Voriconazole } \\
\text { (VZ) }\end{array}$ \\
\hline 1 & C. neoformans & 1 & 4 & 2 & 0.125 \\
\hline 2 & C. neoformans & 0.5 & 2 & 2 & 0.125 \\
\hline 3 & C.neoformans & 0.25 & 2 & $>64$ & 0.125 \\
\hline 4 & C. neoformans & 1 & 4 & 2 & 0.125 \\
\hline 5 & C. gattii & 1 & 2 & 2 & 0.125 \\
\hline 6 & C.neoformans & 0.5 & 2 & 2 & 0.125 \\
\hline
\end{tabular}


Table 3: Percentage of occurrence of symptoms in patients of Cryptococcal meningitis

\begin{tabular}{|c|c|c|}
\hline S.no. & Presenting Symptoms & $\begin{array}{c}\text { Percentage of } \\
\text { occurrence }\end{array}$ \\
\hline 1 & Fever & $83.33 \%$ \\
\hline 2 & Headache & $83.33 \%$ \\
\hline 3 & Vomiting & $50 \%$ \\
\hline 4 & Altered sensorium & $50 \%$ \\
\hline 5 & Seizures & $50 \%$ \\
\hline 6 & Weight loss & $50 \%$ \\
\hline
\end{tabular}

Table 4: Recent data from Indian studies

\begin{tabular}{|c|c|c|c|c|c|c|c|}
\hline S.no. & Researcher & HIV status & $\begin{array}{l}\text { Study } \\
\text { period }\end{array}$ & $\begin{array}{l}\text { No. of } \\
\text { positive } \\
\text { cases/Tot } \\
\text { al cases }\end{array}$ & Prevalence & Species isolated & Mortality \\
\hline 1 & $\begin{array}{l}\text { Lungran et } \\
{\operatorname{al}(2014)^{(9)}}^{(201}\end{array}$ & $\begin{array}{l}\text { Positive and } \\
\text { Negative }\end{array}$ & 2 years & $16 / 48$ & $33.33 \%$ & Cryptococcus spp. & $\mathrm{Nil}$ \\
\hline 2 & $\begin{array}{l}\text { Duggal et al } \\
(2014)^{(10)}\end{array}$ & Positive & 3 years & $46 / 1172$ & $3.92 \%$ & C.neoformans & $40 \%$ \\
\hline 3 & $\begin{array}{l}\text { Dash et al } \\
(2014)^{(11)}\end{array}$ & Positive & $\begin{array}{l}21 / 2 \\
\text { years }\end{array}$ & $16 / 112$ & $14.28 \%$ & C.neoformans & $12.5 \%$ \\
\hline 4 & $\begin{array}{l}\text { Rajani et al } \\
(2014)^{(6)}\end{array}$ & Positive & 1 year & $15 / 50$ & $30 \%$ & C.neoformans & $40 \%$ \\
\hline 5 & $\begin{array}{l}\text { Abhilash et } \\
\text { al }(2015)^{(4)}\end{array}$ & $\begin{array}{l}\text { Positive(112) } \\
\text { Negative (15) }\end{array}$ & 9 years & 117 & $\square$ & C.neoformans & $30.6 \%$ \\
\hline 6 & $\begin{array}{l}\text { Danave et al } \\
(2016)^{(12)}\end{array}$ & Positive & 1 year & $10 / 30$ & $33.33 \%$ & C.neoformans & $\begin{array}{l}\text { Not } \\
\text { mentione } \\
d\end{array}$ \\
\hline 7 & $\begin{array}{l}\text { Das et al } \\
(2017)^{(2)}\end{array}$ & $\begin{array}{l}\text { Positive and } \\
\text { Negative }\end{array}$ & 3 years & $19 / 153$ & $12.41 \%$ & C.neoformans & $42.91 \%$ \\
\hline 8 & $\begin{array}{l}\text { Kadam et al } \\
(2017)^{(13)}\end{array}$ & Positive & 1 year & 208 & $\square$ & C.neoformans & $19 \%$ \\
\hline 9 & $\begin{array}{l}\text { Naik et al } \\
(2017)^{(3)}\end{array}$ & $\begin{array}{l}\text { Positive(88) } \\
\text { Negative (9) }\end{array}$ & $\begin{array}{l}14 \\
\text { years }\end{array}$ & $97 / 277$ & $35 \%$ & C.neoformans & $12.37 \%$ \\
\hline 10 & $\begin{array}{l}\text { Present } \\
\text { study }\end{array}$ & $\begin{array}{l}\text { Positive and } \\
\text { Negative }\end{array}$ & \begin{tabular}{|l|}
6 \\
months
\end{tabular} & $6 / 93$ & $6.45 \%$ & $\begin{array}{l}\text { C.neoformans(5) } \\
\text { C.gatti(1) }\end{array}$ & $66.66 \%$ \\
\hline
\end{tabular}




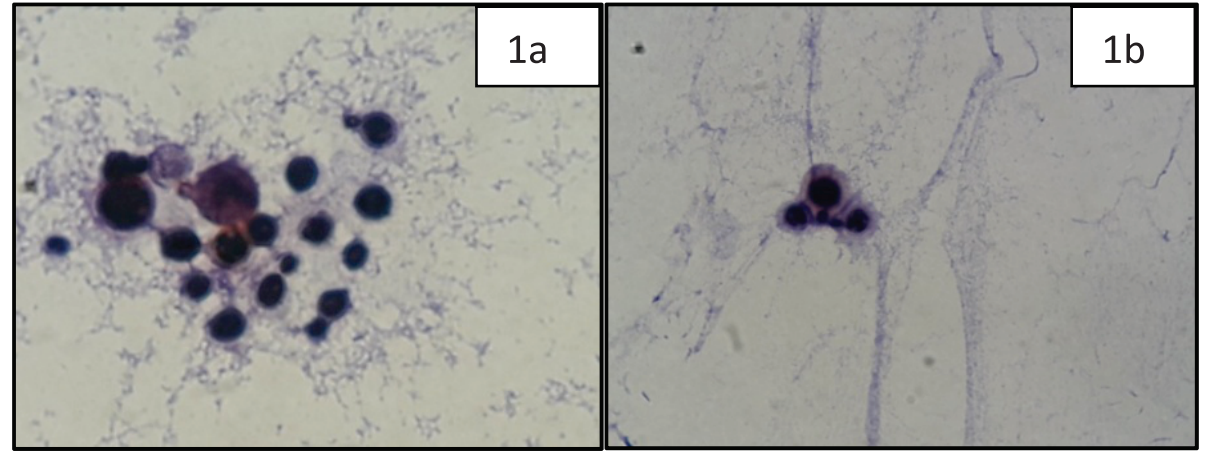

Figure 1a \& 1b: Gram stain showing Gram positive broad based budding yeast cells (magnification 100X)

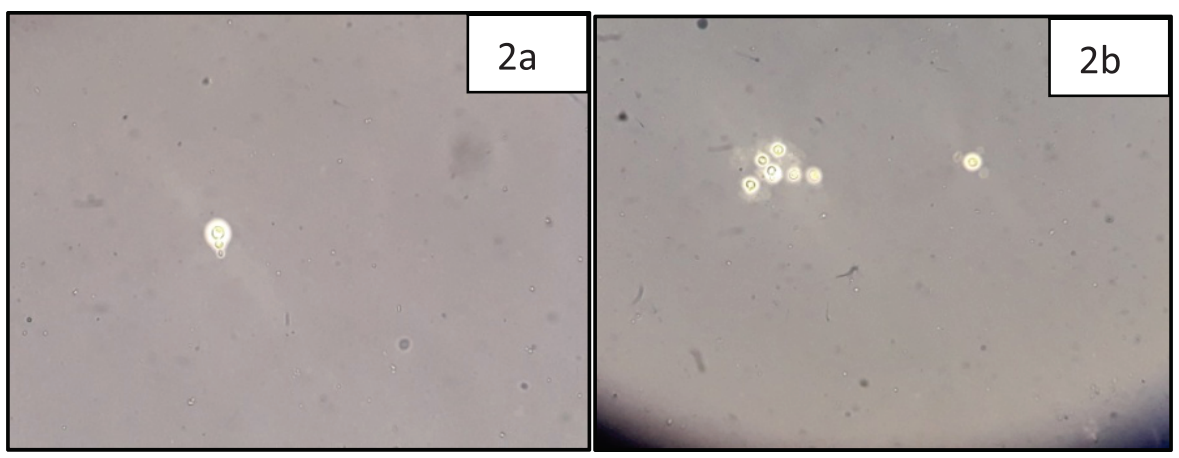

Figure 2a \& 2b: India ink stain showing capsulated budding yeast cells (magnification 40X)

How to cite the article: Bajaj A, Mishra B, Loomba P et al : Prevalence of cryptococcal meningitis in a tertiary care centre. Perspectives in Medical Research 2019; 7(3): 15-21 Sources of Support: Nil, Conflict of interest: None declared 